\title{
The Effect of Principal Managerial Competence and Teacher Professional Competence on Primary School Teacher Performance
}

\author{
Syahminzah Sinaga ${ }^{1 *}$, Bukman Lian ${ }^{2}$, Syaiful Eddy ${ }^{2}$
}

\author{
${ }^{1}$ SD Negeri 1 Anyar \\ ${ }^{2}$ Universitas PGRI Palembang \\ *Corresponding author. Email: syahminzahsinagapohan@gmail.com
}

\begin{abstract}
This research was conducted to provide answers and assertiveness of all assumptions regarding the effect of principal managerial competence and teacher professional competence on teacher performance. To achieve these objectives, the researchers used quantitative research methods. The data were collected by questionnaires, observation, and documentation. The purposive random sampling is conducted that 199 participants from 449 population participated in this study. The location of the research was at Public Elementary School of Kayuagung District, Ogan Komering Ilir Regency. The results obtained from this study are 1) there is a positive and significant influence of principal managerial competence on teacher performance; 2) there is a positive and significant influence on teacher professional competence on teacher performance; 3) Simultaneously the principal managerial competence and teacher professional competence have a positive and significant effect on teacher performance.
\end{abstract}

Keywords: Managerial Competence, Professional Competence, Teacher Performance

\section{INTRODUCTION}

Educational institutions are currently required to continue to innovate in implementing learning. This is not something new, because in every age there will always be updates, especially in the scientific aspect. The technology produced by human knowledge is increasingly developing, even analogous to exceeding the limits of human capabilities, except in the aspect of creation. The greatness of today's technology can be witnessed by the increasingly sophisticated artificial intelligence or artificial intelligence embedded in robots.

Etymologically, the principal is the equivalent of a school principal whose daily task is to carry out the principalship or principal-of-schooling. The term contains the meaning as everything related to the principal's main duties and tasks. This explanation is considered important, because there are several terms to describe the position of school principal, such as school administrators, school leaders, school managers, and so on [1].

Regulation of the Minister of Education and Culture (Permendikbud) Number 6 of 2018, expressly stated in article 15 paragraph (1) states that the workload of a school principal is to fully carry out its main duties and functions as managerial, entrepreneurial development, and supervision of teachers and education personnel [2].

A school principal must be able to manage all activities at school, because it is part of his duties as a manager which means it involves managerial functions. This function is one of the functions that have been carried out during his tenure as school principal. For this reason, a principal must really understand the elements contained in managerial competence.

The skill of the principal to plan and improve school services in order to establish an effective and safe learning environment is known as managerial competence. Principals are required to have skills in developing human resources available in their schools, so that they can really be empowered and contribute to the achievement of educational goals in schools [3]. So it is clear that a principal must be able to understand fundamentally about managerial abilities or managerial competencies.

To support the achievement of educational goals as proclaimed by the principal through his managerial function, a teacher must take responsibility. The form of responsibility that can be given by teachers is by doing their job professionally, by optimizing all their 
competencies. As well as pedagogical competence, professional competence, personal competence and social competence.

Each competency has a role in the development of education, pedagogy, which means the teacher's capabilities in performing learning activities. Mastery of professional competence, that refers to the ability to provide a broad and deep understanding of the subject matter.

This competence is needed by teachers in order to optimize the learning process in the classroom. However, when referring to the applicable regulations regarding education, the term for a teacher is a professional. That way, it is believed that if the mastery of professional competences has been fully carried out by the teacher, the other competencies will be good. Regulation of the Minister of Education and Culture Number 23 of 2017, article 1 paragraph (3) states that teachers are professional educators with the main task of educating, teaching, guiding, directing, training, assessing, and evaluating students in early childhood education through formal education, basic education, and secondary education [4].

Quoting from Law Number 14 of 2005, article 1 paragraph (1) that eachers are trained educators whose primary responsibility is to educate, instruct, guide, lead, prepare, analyze, and evaluate students in early childhood education, primary education, and secondary education [5]. When examined, a teacher has quite a lot of tasks in order to educate the nation's generation as a form of achieving educational goals. Teachers are required to be professional in carrying out their duties, no matter what happens and whatever the conditions that must be experienced. A professional is anyone who provides services or products in compliance with the protocols and regulations of the sector in which they work and is compensated with a paycheck. The person is often a member of a legal body or association created by a country or region's laws [6].

Professional competence means the teacher's mastery of learning material broadly and deeply which allows him to guide students. The mentoring process is carried out to meet the competency standards set by the National Education Standards Agency. As regulated in the Regulation of the Minister of Education and Culture of the Republic of Indonesia Number 137 of 2014, that understanding of the concepts and stages of student development, growth, stimulation, nurturing and protection is an application form of professional competence that must be carried out by teachers in carrying out their duties [7].

That is why, in this study, the competencies discussed are competencies that are considered to be the core of each task for each element. The principal, if he is able to manage the educational institution he leads properly, it will produce a conducive academic atmosphere. Likewise the impact on the implementation of education, through a conducive academic atmosphere the teacher will carry out his duties professionally as one of the main competencies that teachers must have.

Performance as a measure of achievement for a teacher, if a teacher has a good performance it is believed that students will gain meaningful knowledge from the results of learning in class. For this reason, teachers are very important to pay attention to their performance so that instructional learning objectives and educational goals both school and nationally can be achieved. Research conducted by Winaryo [8], the relationship between managerial competences possessed by principals is categorized as strong with school effectiveness. If examined further, the effectiveness of the school is meant one of them is due to optimal teacher performance. Likewise with research conducted by Dahlan[9], that the managerial competence possessed by school principals is able to have an impact on the social competence of teachers. Therefore, it is important for school principals to have good managerial competence. Through these competencies, school management and the surrounding environment can run better.

To support this study, the researcher has conducted a preliminary study into the research location plan. Whereas the results of the preliminary study conducted, the researcher found or identified several things that were considered preliminary findings to be made into phenomena that reinforce the assumptions about the importance of this research. Some of the things obtained include information that the principal is carrying out managerial functions well, but not in every school. Likewise with professional teachers who are currently measured through the form of professional certificates, but after obtaining them, the professionalism of the teachers is assumed not to be better. This is an indication that the teacher's performance is not so good. The aim of this research was to describe the effect of principal managerial competence and teacher professional competence on the performance of primary school teachers in Kayuagung District.

\section{METHODS}

This research was conducted in SD Negeri which is included in the area of Kayuagung District, Ogan Komering Ilir Regency. The time of this research starts from July to September 2020. The research method used in this research is descriptive quantitative research. ElFaradis [11] argues that descriptive research is a form of research carried out with the aim of finding out the existence of independent variables, either in one particular variable or even more than one variable, without making a comparison or connecting with other variables. A quantitative approach is carried out to measure the variables in this study, namely the variables 
$\mathrm{X} 1, \mathrm{X} 2$ and $\mathrm{Y}$ and then look for the relationship between these variables [11].

The population in this study amounted to 449 people, but with purposive sampling technique, the sample was used as many as 119 people. To obtain information from research respondents, questionnaires, observation, and documentation were used.

\section{RESULTS AND DISCUSSION}

The data obtained by the researcher has been analyzed prerequisites, and it is concluded that the data is normally distributed and there is no multicollinearity, which means that the regression equation model used is good

\subsection{Hypothesis testing 1}

The results obtained from testing are as follows:

Table 1. Test Results "t test"

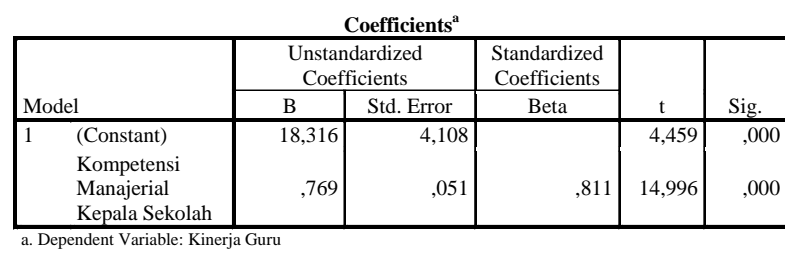

The $t$ value for the principal managerial competence variable is $14.996>\mathrm{t}$ table, namely 1.980 , which means that the alternative hypothesis (Ha) for testing hypothesis 1 is accepted. Therefore, the principal managerial expertise is said to have a strong and important impact on teacher performance.

The test of determination is a test conducted to determine the magnitude of the influence of the independent variable on the dependent variable.

Table 2. Determinant Coefficient $\left(\mathrm{H}_{1}\right)$

\begin{tabular}{|l|r|r|r|r|}
\hline Model & \multicolumn{1}{c|}{ R } & R Square & Adjusted R Square & Std. Error of the Estimate \\
\hline 1 &, $811^{\mathrm{a}}$ &, 658 &, 655 & 1,44363 \\
\hline
\end{tabular}
a. Predictors: (Constant), Kompetensi Manajerial Kepala Sekolah
b. Dependent Variable: Kinerja Guru

The correlation coefficient or the magnitude of the relationship between principal managerial competence and the performance of Public Elementary School teachers in Kayuagung District is $81.1 \% \%$, and is included in the strong relationship category. The determinant coefficient or the magnitude of the influence of the principal managerial competence variable on the performance of Public Elementary School teachers in Kayuagung District is $65.8 \%$ which means it has a high enough influence. The equation for hypothesis 1 is $Y=18.316+0.769 \mathrm{X}$.

\subsection{Hypothesis testing 2}

The results obtained from testing are as follows:
Table 3. Test Results "t test"

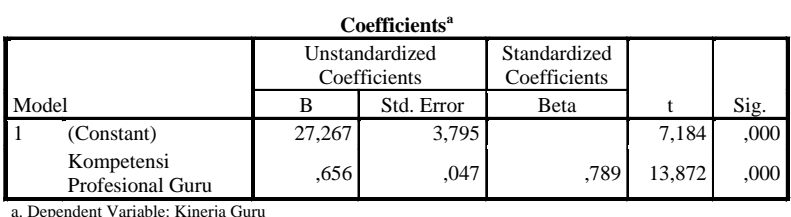

The value of ttable is 1.980 , which means tcount> ttable; 13,872> 1.80. Based on this, it is concluded that the alternative hypothesis is accepted, which means that the professional competence of teachers has a positive and significant effect on the performance of primary school teachers in Kayuagung District.

This is to determine the magnitude of the influence of the independent variable on the dependent variable. In this case, the results obtained are as follows.

Table 4. Determinant Coefficient $\left(\mathrm{H}_{2}\right)$

Model Summary ${ }^{\mathrm{b}}$

\begin{tabular}{|l|r|r|r|r|}
\hline Model & \multicolumn{1}{|c|}{ R } & R Square & Adjusted R Square & Std. Error of the Estimate \\
\hline 1 &, $789^{\mathrm{a}}$ &, 622 &, 619 & 1,51744 \\
\hline
\end{tabular}

a. Predictors: (Constant), Kompetensi Profesional Guru

b. Dependent Variable: Kinerja Guru

The correlation coefficient or the amount of the relationship between teacher professional competence and teacher performance is $78.9 \%$. The magnitude of the relationship, including in the close category. The determinant coefficient or the magnitude of the influence of the teacher professional competence variable on the performance of elementary school teachers in Kayuagung District is $62.2 \%$ and is included in the category of quite high influence. The equation for hypothesis 2 is as follows $\hat{Y}=27.267+0.656 \mathrm{X}$

\subsection{Hypothesis testing 3}

The results obtained from testing are as follows:

Table 5. Test Results "F test"

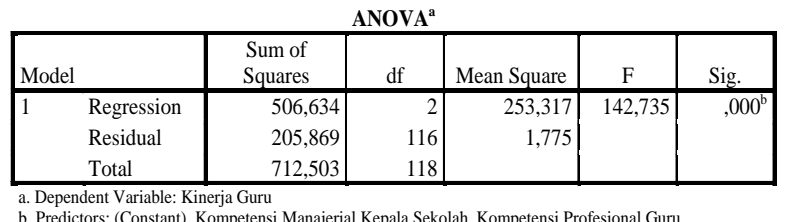

Fcount of $142.738>$ FTabel of 3.074, which means that there is a positive and significant influence of principal managerial competence and teacher professional competence simultaneously on the performance of primary school teachers in Kayuagung District.

Table 6. Determinant Coefficient $\left(\mathrm{H}_{3}\right)$

$$
\text { Model Summary }{ }^{\mathrm{b}}
$$

\begin{tabular}{l|r|r|r|r|}
\hline Model & \multicolumn{1}{|c|}{ R } & R Square & Adjusted R Square & Std. Error of the Estimate \\
\hline 1 &, $843^{\mathrm{a}}$ &, 711 &, 706 & 1,33219 \\
\hline
\end{tabular}
a. Predictors: (Constant), Kompetensi Manajerial Kepala Sekolah, Kompetensi Profesional
Guru
b. Dependent Variable: Kinerja Guru


The value is 0.843 which means that $84.3 \%$ collectively the principal managerial competence and teacher professional competence affect the performance of primary school teachers in Kayuagung District, thus it is included in the category of a close relationship. The managerial competence of the principal and the professional competence of teachers together was able to influence the performance of elementary school teachers in Kayuagung District by $71.1 \%$ and was included in the high influence category. The equation for hypothesis 3 is $Y=16.073+0.474 \mathrm{X} 1+0.322 \mathrm{X} 2$

\subsection{The influence of principal managerial competence on teacher performance}

The magnitude of the influence of the principal managerial competence variable on the performance of Pub.lic Elementary School teachers in Kayuagung District is $65.8 \%$ which means it has a high enough influence. bThese results support research conducted by several previous researchers. Among them was done by Bensalim [11], that the principal's managerial competence was able to have a positive and significant impact on teacher performance at Tarbiyatul Muallimien Al-Islamiyah Putri Al-Amien Prenduan. This study provides information that the effect is $65.7 \%$. Even the results obtained from research conducted at this time were not much different, because the consistent effect was close to the similarity, namely $65.8 \%$. This is clearly an affirmation that can be justified scientifically. A similar study was conducted by Rinrin [12], with the results stating that it is important for a principal to have good managerial competence, because with that, teacher performance can be improved.

More firmly, research on this with similar results, that managerial competence is an important subject that must be possessed by a principal, because of his role as a leader. Thus, the consistency of the influence of the principal managerial competence variable on teacher performance has been tested [13]. Moreover, the principal managerial competence was also able to have an influence on teacher professionalism. That is, this variable does not only have an influence on teacher performance, but is also able to have other positive impacts on other aspects [14]. Likewise with Dahlan [15]. Other studies have also been conducted by Nuraeni [16]. If this is examined in depth, it comes to a point that provides a recommendation that a principal should be able to optimize competence. managerial. Because through this competency, teacher performance, professional competence and social competence will continue to grow optimally.

\subsection{The influence of teacher professional competence on teacher performance}

The determinant coefficient or the magnitude of the influence of the teacher professional competence variable on the performance of elementary school teachers in Kayuagung District is $62.2 \%$ and is included in the category of quite high influence.

These results support the research previously conducted by Mardalena [17]. This study examines the effect of teacher professional competence on teacher performance in public high schools in Tanjung Raja District. Likewise with research conducted by Hasan [18]. Previous research has stated that the professional competence of teachers is able to have a positive impact on teacher performance. That means, the current research also confirms the results of previous research and is able to support the consistency of the influence of teacher professional competence variables on teacher performance [19].

\subsection{The influence of principal managerial competence and teacher professional competence on teacher performance}

Other research that is relevant to what is currently being carried out which states that many things can have an impact on teacher performance [20]. Besides managerial competence and professional competence, a teacher will perform well if he has high work motivation and good work discipline. That is why, the combination of several of these variables becomes material for future correction so that teacher performance can actually get better.

This result is clearly an important information for each stakeholder, because the results confirm that every principal must have good managerial competence and that every teacher must have professional competence, because with the combination of these competencies, the optimization of teacher performance can be carried out continuously. In the end, it is hoped that it can have positive implications for the overall quality of education.

\section{CONCLUSION}

The researchers conclude that 1) principal managerial competence has a positive and significant effect on the performance of primary school teachers; 2) teacher professional competence has a positive and significant effect on the performance of elementary school teachers; and 3) principal managerial competence and teacher professional competence together have a positive and significant effect on the performance of primary school teachers in Kayuagung District.

\section{REFERENCES}

[1] Wikipedia. (2020). Kepala sekolah. Wikipedia.org: https://id.wikipedia.org/wiki/Kepala_sekolah

[2] Kementerian Pendidikan dan Kebudayaan. (2018). Peraturan Menteri Pendidikan dan Kebudayaan 
Nomor 6 Tahun 2018 tentang penugasan guru sebagai kepala sekolah. Jakarta: Kementerian Pendidikan dan Kebudayaan.

[3] Ismuna, Khairudin, \& Djailani, A. (2016). Kompetensi manajerial kepala sekolah dalam meningkatkan kinerja guru pada SD Negeri Lamklat Kecamatan Darussalam Kabupaten Aceh Besar. Jurnal Administrasi Pendidikan, 4(1), 4655 .

[4] Kementerian Pendidikan dan Kebudayaan. (2017). Peraturan Menteri Pendidikan dan Kebudayaan Nomor 23 Tahun 2017 tentang Hari Sekolah. Jakarta: Kementerian Pendidikan dan Kebudayaan.

[5] Pemerintah Republik Indonesia. (2005). UndangUndang Nomor 14 Tahun 2005 tentang Guru dan Dosen. Jakarta: Pemerintah Republik Indonesia.

[6] Wikipedia. (2020, Maret). Profesional. Wikipedia.org:

https://id.wikipedia.org/wiki/Profesional

[7] Kementerian Pendidikan dan Kebudayaan. (2014). Peraturan Menteri Pendidikan dan Kebudayaan Republik Indonesia Nomor 137 Tahun 2014 tentang Standar Nasional Pendidikan Anak Usia Dini. Jakarta: Kementerian Pendidikan dan Kebudayaan

[8] Winaryo, Miyono, N., \& Retnaningdyastuti. (2016). Pengaruh kompetensi manajerial kepala sekolah dan budaya sekolah terhadap efektivitas sekolah di Kabupaten Pemalang. Jurnal Manajemen Pendidikan, 5(3), 287-302

[9] Dahlan, Iriawan, H., \& Hamdan. (2017). Pengaruh kompetensi manajerial kepala sekolah terhadap kompetensi sosial guru di SMA Negeri 11 Makassar. Jurnal Ilmiah Ilmu Administrasi Publik, 7(2), 59-68

[10] Sugiyono. (2017). Metode Penelitian Kualitatif, Kuantitatif dan R\&D. Bandung: Alfabeta.

[11] El-Faradis, F. (2016). Pengaruh Kompetensi profesional kepala sekolah dan motivasi kerja terhadap kinerja guru di Tarbiyatul Muallimien AlIslamiyah (TMI) Putri Al-Amien Prenduan Sumenep Madura. Malang: Universitas Islam Negeri Maulana Malik Ibrahim .

[12] Rinrin, N. (2016). Pengaruh Kompetensi Manajerial Kepala Sekolah terhadap Kinerja Guru di SMK Merdeka Bandung. Bandung: Universitas Pendidikan Indonesia.

[13] Mawaddatullin, N. (2018). Pengaruh Kompetensi Manajerial Kepala Sekolah, Disiplin Kerja dan Motivasi Kerja Guru Terhadap Kinerja Guru di
Sekolah Dasar Negeri Gugus II Kecamatan Kediri Kabupaten Lombok Barat. Jurnal Ilmiah Profesi Pendidikan.

[14] Habibi, B. (2015). Pengaruh kompetensi manajerial kepala sekolah dan motivasi kerja guru terhadap profesionalisme guru SMK Bismen di Kota Tegal. Jurnal Pendidikan Ekonomi Dinamika Pendidikan, X(2), 188-195

[15] Dahlan, Iriawan, H., \& Hamdan. (2017). Pengaruh kompetensi manajerial kepala sekolah terhadap kompetensi sosial guru di SMA Negeri 11 Makassar. Jurnal Ilmiah Ilmu Administrasi Publik, 7(2), 59-68

[16] Nuraeni, Halimah, \& Junaedi. (2019). Pengaruh kompetensi manajerial kepala sekolah terhadap kinerja guru RA PC Weru Kabupaten Cirebon. EduProf, 1(2)

[17] Mardalena, Arafat, Y., \& Fitria, H. (2020) Pengaruh supervisi akademik dan kompetensi profesional guru terhadap kinerja guru di Sekolah Menengah Atas Negeri di Kecamatan Tanjung Raja. Jurnal Intelektualita: Keislaman, Sosial dan Sains, 9(1)

[18] Hasan, M. (2017). Pengaruh Kompetensi Profesional Guru Terhadap Kinerja Guru Ekonomi Sekolah Menengah Atas Negeri di Kabupaten Gowa. Economix, 5(2).

[19] Sopandi, A. (2019). Pengaruh Kompetensi Profesional dan Kompetensi Kepribadian Terhadap Kinerja Guru. Scientific Journal Of Reflection: Economic, Accounting, Management and Business, 2(2).

[20] Alhusaini, A., Kristiawan, M., \& Eddy, S (2020). Pengaruh motivasi kerja dan disiplin kerja terhadap kinerja guru. Jurnal Pendidikan Tambusai, 4(3), 2166-2172. 